Repository of the Max Delbrück Center for Molecular Medicine (MDC) Berlin (Germany)

http://edoc.molc-berlin.de/14142/

\title{
CNS macrophages and peripheral myeloid cells in brain tumours
}

Glass, R., Synowitz, M. 
Title

\section{CNS macrophages and peripheral myeloid cells in brain tumours}

\section{Authors}

Rainer Glass ${ }^{1}$ and Michael Synowitz ${ }^{2,3}$

1 Neurosurgical Research, Department of Neurosurgery, University of Munich, 81377 Munich, Germany.

2 Department of Neurosurgery, Charité - University Medicine Berlin, 13353 Berlin, Germany.

3 Max Delbrueck Center for Molecular Medicine Berlin-Buch (MDC), 13092 Berlin, Germany

\section{Correspondence}

1 Rainer Glass; Neurosurgical Research, Department of Neurosurgery, Ludwig Maximilians University (LMU), Marchioninistr 15, D-81377 Munich; Tel: +49 89 70953148; Email rainer.glass@med.uni-muenchen.de

2 Michael Synowitz; Department of Neurosurgery, Charité - University Medicine Berlin, Augustenburger Platz 1, D13353 Berlin; Tel: +49 30450560 294; Email: michael.synowitz@charite.de

\section{Summary}

Primary brain tumours (gliomas) initiate a strong host response and can contain large amounts of immune cells (myeloid cells) like microglia and tumour infiltrating macrophages. In gliomas the course of pathology is not only controlled by the genetic make-up of the tumour cells, but also depends on the interplay with myeloid cells in the tumour microenvironment. Especially malignant gliomas like glioblastoma multiforme (GBM) are notoriously immune-suppressive and it is now evident that GBM cells manipulate myeloid cells to support tumour expansion. The pro-tumourigenic effects of glioma-associated myeloid cells comprise a support for angiogenesis as well as tumour cell-invasion, -proliferation and -survival. Different strategies for inhibiting the pathological functions of myeloid cells in gliomas are explored and blocking the tropism of microglia/macrophages to gliomas or manipulating the signal transduction pathways for immune cell activation have been successful in pre-clinical models. Hence, myeloid cells are now emerging as a promising target for new adjuvans therapies for gliomas. However, it is also becoming evident that some myeloid-directed glioma therapies may only be beneficial for distinct subclasses of gliomas and that a more cell-type specific manipulation of either microglia or macrophages may improve therapeutic outcome. 


\section{Neuropathological features of gliomas}

Glial tumours constitute approximately $50 \%$ of all newly diagnosed primary brain tumours, with low-grade gliomas accounting for roughly $15 \%$ of all brain tumours in adults [106]. The morphology and the cellular markers for gliomas share some similarities with the main macroglial cell-types (i.e. astrocytes, oligodendrocytes) [75]. Histopathologically, gliomas are divided into four different grades (according to the classification scheme by the world health organization, WHO), in which low-grade tumours are defined as grade-I/-II and high-grade gliomas as grade-III and-IV [87]. The presence of mitotic activity is a key feature for distinguishing low-grade from high-grade gliomas [75]. Statistically, low-grade astrocytomas arise roughly in proportion to the relative mass of the different lobes with most common location within the frontal lobes, followed by temporal and parietal lobe lesions [107]. Overall, 5- and 10-year survival rates of $\sim 70 \%$ and $50 \%$ for grade-I and grade-II gliomas, respectively, have been reported in the literature [25]. The tumour tissue has no obvious signs of neoangiogenesis, infiltrative invasion or inflammation [75]. On the contrary, the outlook for patients with high-grade gliomas is grim. The majority of individuals diagnosed with a grade-IV glioma, which are very heterogeneous tumours and therefore also named glioblastoma multiforme (GBM), have a median progression-free survival of just over half a year and median overall survival of 15-18 months [17], only some subpopulations of patients show median survivals of almost 2 years [54]. GBM is a fast growing, highly angiogenic and invasive tumour and the diffuse growth is a major obstacle for GBM therapy. Other hallmarks of malignant gliomas are break-down of the blood-brain barrier (BBB), many hypoxic areas and necrotic centres [75]. Gliomas are usually diagnosed by neurorimaging (i.e. magnetic resonance imaging) and visualisation of the uptake of a contrast-enhancing agent within the tissue indicates BBB-leakage/breakdown [159]. GBM typically presents as a ragged contrast-enhanced and complex multi-cystic structure. GBM may be diagnosed de novo, i.e. in patients without a clinical history for brain tumours (then named primary GBM) or may evolve from lower grade gliomas (secondary GBM) [103]. 


\section{Multi-modal glioma therapy}

Glioma therapy comprises very different strategies. For patients with deep-seated lesions or lesions located in eloquent regions which are clinically and radiographically indicated as low-grade glioma a conservative management including regular neuroimaging (after obtaining a histological diagnosis) [165], see also [130,150]. Individuals with high-grade gliomas undergo multi-modal treatment combining cytoreductive surgery, radiation- and chemotherapy (using a DNA alkylating agent, Temozolomide; TMZ) [106]. All in all, the approaches to treat high-grade gliomas are largely palliative and substantial efforts are made to improve prognosis and to define markers allowing a stratification of patients into therapeutically relevant phenotypes. Therefore, it was suggested to use gene expression profiling of the tumour mass, which can classify high-grade glioma according to different genetic subtypes (e.g. the proneural, classical or mesenchymal genotype) [19,152,113]. This GBM classification scheme may in the future help to dedicate more individualized and efficient therapies to patients.

\section{Accumulation of myeloid cells in gliomas}

Another striking feature especially of high-grade gliomas is the large number of immune cells, i.e. microglia and macrophages that accumulate in the tumour mass (tumour associated myeloid cells; TAM) [111,7,31]. Peripheral blood-derived macrophages are largely restricted to perivascular areas, the meninx and the choroid plexus in the tumourfree brain, but accumulate in GBM after break-down of the BBB [123]. Microglia is abundant in the tumour-free CNS and comprises between 5\% and 10\% (depending on region) of all brain cells [71,83]; for comparison - the density of neurons is approximately $20 \%$ of cells in the human brain [57]. In GBM the number of TAM can be very high and constitutes up to $30 \%$ of the tumour mass $[5,161,138,125]$, in medulloblastomas even $80 \%$ of all intra-tumoural cells can carry myeloid cell markers [138]. We observed that the distribution of TAM in GBM is very heterogeneous and the average number of these cells is between 20\% and 30\% (M. Synowitz and R. Glass, unpublished data). In most studies the quantification of TAM was performed in GBM samples (which is the most frequent intra-axial brain tumour) and TAM were reported to be less abundant in lower grade gliomas. 


\section{Microglia development}

Microglia and bone-marrow-derived monocytes/macrophages have largely overlapping marker profiles and to date there is no unequivocal method to distinguish both cell types in samples resected from human GBM [162]. This matter is not trivial since monocytes of the peripheral blood and microglia have different developmental origin and may have distinct function in physiology and pathology [129]. In contrast to monocyte-dendritic cell progenitors, microglial progenitor cells are generated in the yolk sac after gestational day 8.5, which is before the onset of definitive hematopoiesis (at E10.5, when monocytes arise) [44]. Both, microglia- and monocyte/macrophage-development depends on the myeloid master transcription factor PU.1 (also named spleen focus forming virus proviral integration oncogene, Spi-1) [73] and on the activity of the receptor for macrophage colony stimulating factor (CSF1R) [44], while the maintenance of microglial cells during adulthood depends on the activity of the tumour growth factor- $\beta$ (TGF- $\beta$ ) receptor-1 [20]. Stimulation of CSF1R in microglia is mediated via macrophage colony stimulating factor (M-CSF) and interleukin 34 (IL34) [44]. This signal transduction pathway is not unique for the generation of microglia alone but is also essential for the generation of peripheral tissue-macrophages in the lung, liver (Kupffer cells) or skin (Langerhans cells) [129]. Generation of monocytes and macrophages during definitive hematopoiesis, in contrast to microglia, requires the transcription factor MYB1 and activation of the fms-related tyrosine kinase (FLT3, a cytokine receptor) [133]. After microglia precursors have entered the developing CNS (between E8.5 and E9.5) they differentiate into microglia and appear to self-renew in the brain throughout live [46]. Microglial cells do not need to be replenished from peripheral sources like the bone marrow [3], but previous experiments indicated that a transient ablation of all myeloid cells can lead to the colonisation of the brain with peripheral macrophages, which could then not be distinguished from bona fide microglia (in terms of morphology and with older sets of markers) [9]. Such experiments were interpreted to support the notion that monocytederived macrophages and microglia largely share the same physiological role. However, today we observe that microglia also have unique roles in the CNS, which are different from classical functions of immune cells [109]. It was e.g. observed that microglia makes 
close contact to pruning synapses and can participate in information processing of neurons [72].

\section{CNS Immunity}

The abundance of TAM in high grade gliomas has been initially been described more than 90 years ago [31] and over several decades researchers focused on delineating the inefficient immune-response of TAM [126,143,39]. It was concluded that the high levels of tumour growth factor- $\beta$ (TGF- $\beta$ ) that are secreted from glioma cells have immunemodulatory functions, which prevents myeloid cells from inducing a coordinated immune response against the tumour [68]. Indeed, it is now evident that TGF- $\beta$ signalling is crucial for microglia in physiology and under neuropathological conditions [20]. However, only a sub-population of microglial cells may participate in controlling the adaptive immune response [49]. The current view is that peripheral macrophages and dendritic cells, in addition to microglia, can perform an important role for immune surveillance in the CNS [123]. Although the brain has no lymphatic vessels, which can transport antigen to deep cervical lymph nodes and to specialized dendritic cells, there are other routes by which peripheral immune cell can scan the immune status of the CNS. Peripheral macrophages can encounter antigen from the CNS, even with an intact BBB, by an exchange of interstitial brain fluids through the cribiform plate and through the choroid plexus into the periphery. Especially during auto-immune neuropathology it is evident that the peripheral immune system can mediate strong immunological action within the CNS. One promising way to exploit the peripheral control of CNS immune functions for brain tumour treatment is pursued by immunotherapy approaches [4]. Here e.g. cytokine application, serotherapy or active immunotherapy (to activate peripheral dendritic cells with antigen of tumour-origin) is used to prime the peripheral immune system to attack gliomas [55]. All in all, it is likely that re-activating antigen-presentation especially in bone-marrow derived immune cells (and additionally a relieve from immune-suppressive signals in tumour infiltrating lymphocytes, see below) would revive a functional anti-tumourigenic response of the adaptive immune system. 


\section{Distinguishing microglia from peripheral macrophages}

It was previously suggested that peripheral macrophages can be distinguished from microglia by means of CD11b and CD45 expression levels in the tumour-free mouse brain [58], in tumour models [7] and in human tumours [110]; while both cell types have high levels of CD11b on the plasma-membrane, only macrophages label intensely for CD45 and microglia have low CD45 levels. However, it is not clear how robust these markers really are in a glioma context; i.e. gliomas may modify the CD-molecule expression in TAM. To our experience, patient derived material often does not allow a distinction between the two cell-types based on CD-markers; most glioma biopsies harbour CD11 $\mathrm{b}^{\text {high }} / \mathrm{CD} 45^{\text {high }}$ cells but biopsies containing CD $11 \mathrm{~b}^{\text {high }} / \mathrm{CD} 45^{\text {low }}$ populations are infrequent (M. Synowitz and R.Glass, unpublished observation). Peripheral and CNS immune cells were previously also distinguished by generating chimeric animals after sub-lethal irradiation and bone-marrow transplantation (e.g. from donors constitutively expressing green fluorescent protein; GFP) [117]. Microglia is radio-resistant and only the hematopoietic cells in the bone marrow are exchanged by this paradigm. This method requires that the brain is shielded from the radiation beam [94] since otherwise the BBB is opened and peripheral immune cells enter the CNS, populate some brain areas and generate tissue macrophages that share many microglial markers [32,169]. Anyway, the radiation procedure causes a massive release of cytokines into the circulation [134] that may also alter brain physiology. Recently, superior methods have been described to unequivocally separate microglia from peripheral immune cells. Genetic mouse models, which indicate developmental markers specifically for microglia or monocytes and monocyte-derived macrophages were generated and now distinct myeloid-cell populations can be observed without generating pathological side effects. It was reported that Flt3-cre induced recombination of an inducible reporter (flox-STOP-flox-YFP) very efficiently marks bone marrow-derived myeloid cells but spares microglia [133,46]. Also, a model was established to specifically indicate microglia using recombination (and activation) of an inducible reporter under control of the gene promoter for the fraktalkine receptor (Cx3cr1). Timed activation of Cx3cr1-CreErt2 by Tamoxifen application in transgenic animals crossed to a flox-STOP-flox reporter initially marks all myeloid cells, but the physiological turnover of peripheral monocytes and monocyte-derived 
macrophage depletes reporter-positive immune cells from the peripheral blood while labelled microglia persists [45]. In another approach to distinguish microglia and bloodborne myeloid cells, microglia was purified from physiological, blood-free brain samples and monocyte-derived macrophages were purified from peripheral blood, then direct RNA sequencing was used to identify differentially expressed genes in both cell-types [58]. Interestingly, it was found that certain purinergic receptors (like $\mathrm{P}_{2} \mathrm{Y}_{12}$ ) or surface molecules (like Siglec-H) are exclusive markers for microglia. Future work (e.g. using genetic recombination in transgenic models) will need to show if these differences persist in gliomas; if this is the case the it will be possible to therapeutically treat gliomaassociated microglia specifically (e.g. with purinergic compounds) or to identify microglia in glioma immunohistochemically.

\section{Microglial activation and innate immunity}

Classically, the immune cell function of microglia was observed after challenging the brain with bacterial pathogens (e.g. after sterile infection with lipopolysaccharides; LPS), these studies showed that microglia can undergo remarkable morphological changes [76] and become motile [1]. It was speculated that microglia revert from a "resting" state (associated with a stellate cell-shape) towards a motile and activated phenotype (associated with an amoeboid cell-shape) [121]. However, real-time observations by intravital microscopy revealed that microglia under physiological conditions are not immotile (as the term "resting" infers), but constantly scan the environment [121,30,100]. If lesions to the brain parenchyma are encountered, then microglial cells initiate a damage response, which can (depending on the extent of the lesion) also include other brain cells like astrocytes [50]. While the protection of the CNS from infection or injury is certainly a task for microglial cells, current studies also acknowledge the tissue protective role of microglia and show that these cells may contribute to neuronal survival in different neuropathologies [109]. Overall, it is established that microglia has a prominent role during acute inflammation. Here, pathogens activate microglia via stimulation of toll-like receptors (TLR), then microglia phagocytose [124] or kill microorganisms, by releasing reactive oxygen species (ROS)[69] or nitric oxide (NO) [35] and e.g. secrete inflammatory cytokines like tumour necrosis factor- $\alpha$ (TNF- $\alpha$ ), interleukin-6 (IL-6), 
IL10 and IL12 [62]. The physiological response of microglia to inflammatory pathogens is summarised as the M1-type of microglial activation [16]. Microglial cells also control the resolution of inflammatory events and participate in tissue repair functions including the induction of angiogenesis in lesioned areas [137,16]. During homeostasis the parenchymal cells, in particular neurons, present several plasma membrane molecules and release CX3CL1, which are recognised by microglia and prevent their activation $[51,129]$. The pro-inflammatory and tissue protective functions of microglia may also become apparent in gliomas but in a tumour environment they were, in most studies, not separated from the inflammatory reactions of monocyte-derived macrophages. Here, gliomas secrete IL4, IL6 and IL10 [139], as well as TGF- $\beta$ [144] that induce an alternatively activated phenotype in TAM, which is referred to as M2-type of activation [78]. Increased production of prostaglandin E2 $\left(\mathrm{PGE}_{2}\right)$ by glioma is associated with suppression of T-cell and TAM activation and plays an important role in the generation of an immunosuppressive environment [98]. The cell death pathway molecule FASligand (CD95-L or FASL) was found to be expressed by human GBM and both TAM and T-cells express the FASL receptor (FAS). It was recently reported that FASL contributes to local immunosuppression whereas there is no evidence that GBM-derived FASL induces TAM apoptosis [65]. TGF- $\beta$, macrophage-CSF (M-CSF), IL-4 and IL-10 mediate an M2 phenotype of TAM. M2-activated TAM have e.g. reduced MHC-II levels [132], release IL10 [171,157], upregulate GM-CSF, IL-10, CXCL14 [42] and vascular endothelial growth factor (VEGF) [101] and have increased expression of Arginase-1 [37]. M-CSF expression in glioblastomas correlates with the expression of the M2 marker CD163 in TAM [78]. Both microglia and monocyte-derived macrophages share these M1 and M2 features in neuropathology as well as in high-grade gliomas and the NF-KB and the signal transducer and activator of transcription-3 (STAT3) pathways have central roles in shifting TAM between M1 and M2 phenotypes [170,120,77]. Manipulation of the related signalling cascades may become a possibility to promote the anti-tumourigenic M1 type in TAM [59,2]. It should also be noted that a prototypical M1 phenotype (as initiated by LPS) or M2 polarisation (as observed during the resolution of inflammation) is usually not encountered in TAM [37,42]. It was observed that TAM in gliomas have an aberrant immune-type and share both M1 and M2 features (Fig. 1). Currently it is 
unknown if myeloid cells homogenously have a mixed M1/M2 type or if there are distinct TAM subsets (subtypes of microglia as well as monocyte-derived macrophages) which are either more in the M1 or the M2 spectrum. Altogether, earlier work suggested that microglial cells were brain macrophages which can switch between "on" and "off" modes of activation - this image is now reverted and we see that microglia and monocyte-derived macrophages are assigned with an array of different brain-specific roles during physiology and pathology, which are not necessarily reflected by morphological changes.

\section{Adaptive immune functions in gliomas}

Systemic immunosuppression in patients with primary intracranial tumours has been well documented [163]. Deficits in the adaptive immune response of glioma patients are induced by tumour-released immune-modulatory cytokines [39,68] and partly by clinically applied corticosteroids (Dexamethasone) [8], which are given to reduce gliomaassociated edema [148]. Glioma patients have low peripheral lymphocyte counts, reduced delayed-type hypersensitivity reactions to recall antigen, impaired mitogen-induced blastogenic responses by peripheral mononuclear cells, and increased levels of CD8 ${ }^{+}$ suppressor T-cells [81]. The lymphocyte deficit involves the T-helper $\left(\mathrm{CD} 4^{+}\right)$subsets with decreased T-cell activity in vitro. Furthermore, there is diminished induction of immunoglobulin synthesis by B-cells in vitro from the peripheral blood of patients with intracranial tumour, probably related to diminished T-helper activity [14].

Only activated T-cells can traverse the BBB and gain entry to the brain [123]. Then, brain infiltrating $\mathrm{CD}^{+}{ }^{+}$T-cells may lose the activated status through the action of TGF- $\beta$ released from glioma cells or TAM [151], or from TAM secreting IL-10 and C-C chemokine ligand-17 (CCL17), CCL18 or CCL22 [162]. Cytokines like TGF- $\beta$ have been shown to suppress the production of both IL-1 and human leukocyte antigen (HLA) class-II molecules by antigen-presenting cells, and also suppresses the activation and proliferation of cytotoxic T lymphocyte (CTL) [64]. In GBM patients, systemic immune responses are unable to overcome the immunosuppressive tumour microenvironment and patients have reduced T-cell responses due to a number of factors including impaired Tcell receptor (TCR) signalling, immunosuppressive cytokines, T-cell anergy (mediated by 
regulatory $\mathrm{T}$-cells, $\mathrm{T}_{\text {reg, }}$, induced immune suppression), and dysfunctional antigenpresenting cells $[97,142]$. Another study on GBM has shown that TAM had surface HLA class-II expression but lacked expression of the co-stimulatory molecules CD80, CD86, and CD40 critical for T-cell activation and thus were unable to activate T-cells [60]. Also, in GBM, there is a lack of effector and/or activated CTL and a relative abundance

of $\mathrm{T}_{\text {regs }}$ [158]. One important aspect is a dramatic reduction in the expression of HLA molecules on the surface of tumour cells [67], which weakens their detection by CTL.

Differential activation of STAT3 in TAM can control multiple immunosuppressive pathways in high-grade gliomas [162]. STAT3 activation in TAM is induced by different cytokines of the tumour microenvironment such as IL-10, IL-6, epidermal growth factor (EGF) and fibroblast growth factor. Activated STAT3 is known to reduce the expression of surface molecules necessary for antigen presentation such as MHC-II, CD80, and CD86 [79], as well as to increase the expression of many M2-specific immunomodulatory mediators including IL-10, EGF, VEGF, and various matrix metalloproteinsases (MMPs) [18]. It is currently unclear whether a single dominant molecule or a complex network of molecules is responsible for the immunosuppressive phenotype of glioma TAM, but STAT3 activation appears to play a key role in generating and perpetuating the M2-shifted TAM in gliomas.

\section{The pro-invasive function of myeloid cells in gliomas}

A specific role for microglial cells in brain tumours was addressed two decades ago $[47,143]$. Initially, in vitro studies showed that microglia, which can be purified from the fetal mouse or from the rat brain and maintained for limited times in cell culture, has profound effects especially on the invasiveness of glioma cells [95,6]. A seminal studies using Boyden chamber migration assays demonstrated that the presence of microglia facilitates the transmigration of glioma cells through a matrix containing barrier [11]. Especially the use of cultivated brain slices, which assures the preservation of original three-dimensional cellular context of the brain in an in vitro setting, has advanced our understanding of the specific role of microglia in gliomas [104,91]. Glioma cells, stably expressing a fluorescent reporter protein, can be inoculated into brain slices and the motility of the tumour cells can be monitored in real-time under conditions closely 
resembling the in vivo situation. These slice cultures are a method of choice when a pharmacological treatments are investigated, since compounds that otherwise do not traverse the blood brain barrier can be applied into the tumour area. Furthermore, microglia can maintain their normal surveillance-function function scanning the brain for potential lesions (see above) and the role of microglial cells in gliomas can be investigated without the intratumoural accumulation of monocyte-derived macrophages. Techniques have been developed to specifically ablate microglia in brain slices without deteriorating the entire cellular architecture of such slice preparations. In tumourinoculated brain slice preparations the application of Clodronate-filled liposomes was instrumental to uncover important pro-pathological action of tumour-associated microglial cells [91]. The liposomes are rapidly and specifically taken-up by the phagocytic microglia and the payload (Clodronate) induces cytotoxicity. The dying microglia initially promotes astrocyte activation, which ceases after a relatively short interval (of three days). As a control, brain slices can be replenished (after Clodronate application) with exogenously cultivated microglia and the pro-tumourigenic effects are re-installed [91]. The course of tumour progression in microglia-containing versus microglia-depleted slices can be compared in this model. These experiments corroborated that microglia indeed has a pro-invasive effect in gliomas - as postulated from earlier cell culture studies. Conditioned media from the (glioma containing) brain slices had increased metalloprotease-2 (MMP2) activity only when microglia was present and then individual glioma cells invaded deeper into the brain tumour parenchyma. Importantly, this study showed that microglia promotes the activity of MMP2, but does not alter the expression levels of this enzyme. Metalloproteases are synthesised and secreted as inactive pro-forms and only the proteolytic cleavage of a peptide moiety converts the pro-enzyme into its active form [135] Then the active MMP2 can degrade extracellular matrix and facilitate glioma invasion. Subsequent studies with different mouse models supported these in vitro findings [93,154,92]. Ablation of myeloid cells by intra-tumoural application (via osmotic mini-pumps) of Ganciclovir in glioma-bearing animals engineered to express the herpes simplex thymidine kinase (HSVTK) gene, which converts of the pro-drug Ganciclovir into an active cell-death inducing agent, under a promoter for CD11b (Cd11b-Hsvtk) drastically diminished TAM numbers in 
gliomas and largely reduced glioma size [92]. The molecular signalling pathway responsible for the glioma-supporting effect of TAM was uncovered and manipulated in another in vivo model. Here, we (and subsequently others) found that glioma cells release a (still unknown) soluble factor that triggers toll-like receptor-2 (TLR2)[154], which promote the activity of mitogen activated kinase (MAPK) p38 and of the TLR signal transducer MYD88 [92] in TAM. The MYD88 molecule induces the expression of another metalloprotease named membrane type-1 metalloprotease (MT1-MMP) on the plasma membrane of TAM. TAM-expressed MT1-MMP converts pro-MMP2 into activeMMP2 thereby facilitating glioma motility (Fig. 2).

The extracellular matrix in the brain has a different biochemical composition and architecture as compared to peripheral tissues like e.g. epithelia [99,33,127]. In epithelial tumours matrix-degradation and disruption of the epithelial layering is a hallmark for tumour progression and malignancy [99]. In the brain extracellular matrix components are less abundant and the matrix is heterogeneous between areas of grey and white matter, basement membranes are predominantly found along the vasculature, the meninges and parenchyma bordering with the ventricles [127]. Metalloproteinasemediated matrix degradation is therefore associated with different pathological effects as compared to epithelia and can result in increased invasion of glioma cells along the vasculature or also opening of the blood brain barrier [153,10,61]. MMP-activity has also signalling effects and can unmask cryptic amino-acid residues in the matrix[108,155], which stimulate growth factor receptors or bind to different integrins on tumour cells and can thereby support tumour expansion [149].

\section{The pro-angiogenic role of myeloid cells in gliomas}

Another major role for MMPs on TAM is to initiate and to support the formation of new intra-tumoural blood vessels. The activity of MT1-MMP in concert with MMP2 disrupts basement membranes on blood-vessels and allows endothelial cell sprouting [149]. Additionally, TAM prime endothelial cells to sproute as they synthesize and release TNF- $\alpha$ and also other angiogenic molecules which have direct angiogenic effects or promote the secretion of vascular endothelial growth factor from glioma cells $[140,101]$ (Fig. 3). The sprouting endothelia in gliomas need to be coordinated to form functional 
vessels and especially the microglial cells may control this step, too. During development microglia localizes to vessel branch points, guides the endothelial tip-cells towards each other, induces tip- to stalk-cell conversion in the endothelia and thereby assures the building of functional vascular tubes [147]. TAM also express the pro-angiogenic MMP9 [63] or induce the expression of MMP-9 in glioma (stem) cells [167]. MMP-9 participates in modifying the basement membrane and liberates growth factors like stem cell factor (SCF) [82] that acts as a specific agonist for the tyrosine kinase KIT. The KIT signalling pathway can recruit bone marrow-derived endothelial precursors to tumours and thereby augment the formation of vascular structures by a mechanism termed vasculogenesis [146]. However, another study suggested that vasculogenesis has only a minor role in GBM and that vascular sprouting and vessel cooption are the main drivers for the formation of new blood vessels in gliomas [89]. It is likely that microglial cells have a specific role in the initial steps of intratumoural vascularization (when the BBB is intact and macrophages have not yet invaded the brain), subsequently the sprouting endothelia and later the monocyte-derived macrophages, which invade into the tumour, will also release pro-angiogenic signalling molecules and perpetuate the formation of vascular structures in gliomas. As described above, anti-angiogenesis was regarded as a promising therapeutic strategy [102], but application of the VEGF-A-blocker Bevacizumab has clinically failed [90]. It is currently a matter of intense investigation if TAM can mediate resistance to Bevacizumab by releasing angiogenic factors alternatively to VEGF-A. Myeloid cells accumulating in GBM can promote the acquisition of a mesenchymal tumour-subtype [84,38,34], which is associated with resistance to Bevacizumab [114,115]. However, as with most pathways controlled by TAM, support of angiogenesis is only one side of the intra-tumoural actions of these immune cells in gliomas. Myeloid cells also inhibit intra-tumoural vessel formation e.g. by liberating angiostatins from the extracellular matrix, by activity of the urokinase type plasminogen activator [74]. In brain tumours the net effect of TAM pro- and antitumourigenic activity is on the tumour supporting side, but there may be a possibility to shift this balance and promote the anti-tumour effects of glioma associated microglia or of blood-borne macrophages that invaded into primary brain tumours. 
Adenosine-5-triphosphate (ATP) was shown to stimulate the production of chemokines and CCl2 (MCP-1) and interleukin-8 (IL-8) in gliomas [66]. Nucleosides like adenosine modulate in an auto- and paracrine fashion the fine-tuning of the tumour-stromainteraction [15]. Extracellular adenosine itself is not only a passive product of tumour induced ischemia, hypoxia and necrosis but also actively released due to altered purine metabolism [85]. Most of the signalling actions of extracellular adenosine are mediated by G-protein-coupled cell-surface receptors that are divided into four subtypes: $A_{1}, A_{2 A}$, $A_{2 B}$ and $A_{3}$ [40]. Adenosine has several inhibitory effects on M1 macrophage activation which are mediated by $\mathrm{A}_{2 \mathrm{~A}}$ receptors [53] and increases M2 macrophage activation [28]. VEGF production by macrophages is stimulated through $A_{2 A}$ receptors and therefore it can support angiogenesis [122]. Microglial cells express functional $\mathrm{A}_{1 \mathrm{~A}}$ receptors and in gliomas selective stimulation of $\mathrm{A}_{1 \mathrm{~A}}$ inhibits the TAM activation $[88,145]$.

\section{Blocking the tumour supporting phenotype of myeloid cells}

While the abundant expression and release of TGF- $\beta$ in gliomas was initially attributed only to the tumour cells, it now established that myeloid cells also generate TGF- $\beta$ and thereby mediate important pathological effects $[164,68,166]$. In addition to blunting adaptive immune responses TGF- $\beta$ was also observed to have direct effects on the highly aggressive subset of stem-like glioma cells especially in tumours of the mesenchymal genotype [112]. Application of Amphotericin-B can induce a tumour stem cell suppressive phenotype in TAM and mediates profound therapeutic effects in mouse models [131].

Of note, the ablation of myeloid cells in a mouse glioma model (using Cd11b-Hsvtk transgenic animals; see above) has also shown anti-tumour effects of TAM, previously. Here, systemic application of Ganciclovir was used which may have preferentially reduced the number of monocytes in the peripheral blood and monocyte-derived macrophages (which accumulate in gliomas) and under these settings an antitumourigenic role for myeloid cells in gliomas was observed [43]. The anti-tumourigenic function of the macrophage population was addressed to their antigen-presenting capacity and to their ability to activate T-lymphocytes. Again, these results suggest that TAM have the capacity to mediate both pro- and anti-tumour effects and that it will be 
interesting to dissect the function of intra-tumoural monocyte-derived macrophages or microglia in order to establish cell-type specific targets for adjuvans therapies for gliomas.

The Flt3-cre [46] and Cx3cr1-CreErt2 [45] based models, in addition to newly established cell-surface markers [58], will advance our understanding of the cell-specific traits of microglia- or monocyte-derived macrophages in gliomas. Nevertheless, it is likely an oversimplification to regard either immune-cell population as homogenous [119]. There is solid evidence that microglia are heterogenic with respect to different brain areas and that they also undergo changes during aging [52]. These differences may not cause too much variance in experimental glioma models where tumour localisation, timing of tumourigenesis and genetic background of gliomas can be tightly controlled [23]. However, when analysing patient-biopsies heterogeneity is an issue since gliomas are located to different brain areas, patient-age can differ by several decades and gliomas are caused by a range of genetic mutations with consequences for cell-signalling and immunogenicity $[87,103]$. One way of patient stratification is to obtain glioma samples and to investigate the gene expression pattern assigning tumours to distinct genetic subclasses [19,152]. Preclinical glioma models indicated that this approach is important to identify individuals that may respond to myeloid-directed brain tumour therapies $[118,12]$. Blockade of CSFR1 signalling specifically in TAM by a small molecule inhibitor (BLZ945) had very robust anti-tumourigenic effects in a mouse glioma model resembling the proneural GBM-type [118]. Importantly, BLZ945 largely abrogated the tumour supporting function of TAM in a mouse model and the beneficial effects of CSFR1-inhibition were associated with the induction of a gene-expression signature that also served to predict improved survival in human GBM of the proneural subtype but not in other GBM subtypes. Another CSFR1 inhibitor (PLX3397) inhibited glioma cell invasion in an orthotopic implantation model using immune-competent mice [26]. However, in our hands CSF1R-inhibition did not mediate any anti-tumour effects, when using a related glioma mouse model (M. Synowitz and R. Glass, unpublished observations); suggesting that subtle differences in experimental procedures may have profound impact, when investigating TAM. Several studies suggest that inter-individual differences between gliomas, in particular the genetic subtype of tumours, can be of 
importance to predict the outcome of immune-cell targeting therapies [84,38,34]. This is not surprising since the genetic subtype is determined from the entire tumour biopsy, which includes TAM. During progression and relapse GBM can convert from the proneural to the mesenchymal type $[13,21,27]$ and it was shown that TNF- $\alpha$ release form intra-tumoural myeloid cells and TNF- $\alpha$ induced NF-kappa-B signalling in stem-like glioma cells can promote the conversion of the GBM genotype [12]. The shift from the proneural towards the mesenchymal glioma phenotype can promote radiation resistance in a subset of the proneural tumours. This has profound therapeutic implications, as NF$\mathrm{KB}$ blockade may be an important strategy to improve the outcome of radiotherapy. Altogether, the studies on the tumour-modulating effects of TAM in gliomas show that the expression signature has some predictive value for the application of e.g. BLZ945, but also indicate that the proneural subtype is not homogenous and that some proneural gliomas are sensitive to a TAM-induced mesenchymal drift. Hence, a better understanding of the gene expression pattern of TAM in glioma is necessary to e.g. stratify patients according to new myeloid cell-targeting adjuvans treatments that comprise CSFR1-inhibition or NF-KB blockade plus irradiation. The molecular analysis of tumour biopsies and different glioma cell subsets has largely advanced our understanding of the pathological processes in malignant brain tumours. Similar techniques have already been used in several pioneering studies to uncover prognostic markers and signalling pathways of myeloid cells in gliomas or neuropathological disease. With more studies on the genetic make-up of microglia and monocytes-derived macrophages in glioma mouse models we will obtain a more detailed picture on the potential therapeutic targets in subsets of TAM. The larger challenge ahead is to obtain similar data on TAM in human brain tumours, where we do not have easy access to relevant control samples from the tumour-free human brain (so different controls form post-mortem material and epilepsy surgery will be necessary) and where it will be difficult to prove if the markers distinguishing microglia and blood-borne macrophages in the mouse brain also apply to human cells. 


\section{The tropism of myeloid cells to gliomas}

In the past, additional TAM targeting strategies in preclinical glioma models also had beneficial effects. Application of the clinically approved immune-suppressive drug cyclosporine-A could strongly inhibit the pro-tumourigenic effects of myeloid cells in glioma $[96,141,24]$. Other investigator used stimulation of TLRs in glioma cells and in TAM as a therapeutic paradigm $[48,36,70]$. Another way to interfere with the tumour promoting role of myeloid cells in gliomas is to blunt the intra-tumoural accumulation of these immune cells by blocking chemoattractive signalling. Experiments using encapsulated glioma cells showed that glioma-released soluble factors have major role in guiding myeloid cells towards the tumour mass. Here, glial-derived neurotrophic factor (GDNF) predominated chemoattraction of microglia in vitro, GDNF induced a tropism for myleoid cells towards gliomas in vivo and GDNF-knockdown in gliomas had a therapeutic function [80]. Other studies showed that CCL2 (MCP-1), CCL5, CCL7, VEGF-A [116,105,168] or (in hypoxic areas) stromal derived factor-1 [160] have prominent tropic function for myeloid cells in gliomas (Fig. 2). In contrast to the function of CX3CR1 in physiology, which promotes a resting state in microglia [51], the same receptor can promote myeloid cell recruitment to human brain tumours and thereby support tumour expansion [56], but had no pathological role in a mouse model [86]. A recent publication suggests hypoxia-induced Semaphorin 3A (Sema3A) as a potent attractant for TAM by triggering VEGF-receptor-1 phosphorylation through the associated holoreceptor, composed of Neuropilin-1 (NRP1) and PlexinA1/PlexinA4. Importantly, whereas NRP1 levels are down-regulated in the hypoxic environment, Sema3A continues to regulate TAM in an NRP1-independent manner by eliciting PlexinA1/PlexinA4-mediated stop signals, which retain them inside the hypoxic niche [22]. Again, it is presently not known if these many different chemotropic molecules are active either in different glioma subtypes, or glioma models of distinct genetic backgrounds, if all myeloid cells respond equally to these pro-migratory cues or if there are distinct immune cell-subtypes which have a preference for the one or the other chemoattractive signalling pathway. 


\section{Future directions}

To date most studies on myeloid cells in glioma have uncovered specific pro- or antitumourigenic function of myeloid cells in the untreated tumour. Especially in pre-clinical models distinct roles of TAM in tumour-antigen presentation, promotion of gliomainvasion or angiogenesis were described. These data were backed up with findings from human biopsies, with the caveat that humans usually are treated with Dexamethasone before surgical tumour resection. Some exciting data are also available on the impact of myeloid cells on glioma treatment using irradiation [12,128]. It was observed that myeloid cells can support glioma cell survival and prevent the accumulation of antitumourigenic reactive oxygen after radiochemotherapy. The myeloid cells provide alternative metabolites to glioma cells (quinilonic acid instead of NADH), which prevent the generation of reactive oxygen species that mediate some of the beneficial effects of radiochemotherapy [128]. Also it was shown that the composition of myeloid cellsubtypes is altered throughout radiochemotherapy, with as yet unknown consequences for the therapy of glioma relapse [136]. One important topic that has not received much attention so far is the role of microglia during tumour formation and progression form low-grade to high-grade stages. It is postulated that gliomas arise from neoplastic transformation of stem and precursor cells (NPCs) in the brain or from de-differentiating astrocytes [23,41]. Microglia has been proven to be of importance for the turnover of NPCs $[29,156]$ and it remains to be shown if microglia (e.g. during brain inflammation) contributes to the acquisition of somatic mutations in pre-neoplastic brain cells, which can drive tumourigenesis. Importantly, it was recently observed in a transgenic mouse model that CSFR1 blockade (by BLZ945) in myeloid cells can largely prevent/ slowdown malignant progression of neoplastic brain cells into high-grade gliomas [118]. Given that there are often little treatment options for patients with low-grade gliomas it will be important to explore if tackling the glioma-associating microglia can prevent the malignant transformation of lower grade tumours. For basic science studies investigating the role of microglia in gliomas there is the advantage that lower-grade gliomas have an intact $\mathrm{BBB}$, which implies that nor monocyte-derived macrophages have entered the 
tumour area, and hence specifically the pathological impact of glioma-associated microglia can be studied in biopsies from human tumours.

Altogether, we have now firm evidence that TAM are pathologically important and potential targets for adjuvans treatment of gliomas. Currently, we see an array of pro- and anti-tumourigenic effects of microglia or monocyte-derived macrophages, which make it difficult to directly translate immune cell-directed therapeutic approaches into clinical procedures. Uncovering the inter-individual heterogeneity of TAM in brain tumours and defining distinct pro- or anti-tumourigenic functions in microglia or blood-borne macrophages (and in subtypes of these cells) will help to set-up promising therapies and to locate patients that may profit from new TAM-targeting treatments. 


\section{Acknowledgements}

Financial support for R.G. by the Deutsche Forschungsgemeinschaft (SFB824, GL691/2), Anni-Hofmann Stiftung and by the German Cancer Consortium (DKTK), Heidelberg, Germany and for for M.S. by the Deutsche Forschungsgemeinschaft (SY 144/3) is gratefully acknowledged. 


\section{References}

1. abd-el-Basset E, Fedoroff S (1995) Effect of bacterial wall lipopolysaccharide (LPS) on morphology, motility, and cytoskeletal organization of microglia in cultures. Journal of neuroscience research 41 (2):222-237. doi:10.1002/jnr.490410210

2. Adach A, Ellert-Miklaszewska A, Kaminska B (2009) Molecular characterization of STAT signaling in inflammation and tumorigenesis. Methods Mol Biol 512:265278. doi:10.1007/978-1-60327-530-9_14

3. Ajami B, Bennett JL, Krieger C, Tetzlaff W, Rossi FM (2007) Local self-renewal can sustain CNS microglia maintenance and function throughout adult life. Nature neuroscience 10 (12):1538-1543. doi:10.1038/nn2014

4. Badhiwala J, Decker WK, Berens ME, Bhardwaj RD (2013) Clinical trials in cellular immunotherapy for brain/CNS tumors. Expert review of neurotherapeutics 13 (4):405-424. doi:10.1586/ern.13.23

5. Badie B, Schartner J (2001) Role of microglia in glioma biology. Microsc Res Tech 54 (2):106-113

6. Badie B, Schartner J, Klaver J, Vorpahl J (1999) In vitro modulation of microglia motility by glioma cells is mediated by hepatocyte growth factor/scatter factor. Neurosurgery 44 (5):1077-1082; discussion 1082-1073

7. Badie B, Schartner JM (2000) Flow cytometric characterization of tumor-associated macrophages in experimental gliomas. Neurosurgery 46 (4):957-961; discussion 961-952

8. Badie B, Schartner JM, Paul J, Bartley BA, Vorpahl J, Preston JK (2000) Dexamethasone-induced abolition of the inflammatory response in an experimental glioma model: a flow cytometry study. Journal of neurosurgery 93 (4):634-639. doi:10.3171/jns.2000.93.4.0634

9. Beers DR, Henkel JS, Xiao Q, Zhao W, Wang J, Yen AA, Siklos L, McKercher SR, Appel SH (2006) Wild-type microglia extend survival in PU.1 knockout mice 
with familial amyotrophic lateral sclerosis. Proceedings of the National Academy of Sciences of the United States of America 103 (43):16021-16026. doi:10.1073/pnas.0607423103

10. Bello L, Lucini V, Carrabba G, Giussani C, Machluf M, Pluderi M, Nikas D, Zhang J, Tomei G, Villani RM, Carroll RS, Bikfalvi A, Black PM (2001) Simultaneous inhibition of glioma angiogenesis, cell proliferation, and invasion by a naturally occurring fragment of human metalloproteinase-2. Cancer research 61 (24):87308736

11. Bettinger I, Thanos S, Paulus W (2002) Microglia promote glioma migration. Acta Neuropathol (Berl) 103 (4):351-355

12. Bhat KP, Balasubramaniyan V, Vaillant B, Ezhilarasan R, Hummelink K, Hollingsworth F, Wani K, Heathcock L, James JD, Goodman LD, Conroy S, Long L, Lelic N, Wang S, Gumin J, Raj D, Kodama Y, Raghunathan A, Olar A, Joshi K, Pelloski CE, Heimberger A, Kim SH, Cahill DP, Rao G, Den Dunnen WF, Boddeke HW, Phillips HS, Nakano I, Lang FF, Colman H, Sulman EP, Aldape K (2013) Mesenchymal differentiation mediated by NF-kappaB promotes radiation resistance in glioblastoma. Cancer Cell 24 (3):331-346. doi:10.1016/j.ccr.2013.08.001

13. Bhat KP, Salazar KL, Balasubramaniyan V, Wani K, Heathcock L, Hollingsworth F, James JD, Gumin J, Diefes KL, Kim SH, Turski A, Azodi Y, Yang Y, Doucette T, Colman H, Sulman EP, Lang FF, Rao G, Copray S, Vaillant BD, Aldape KD (2011) The transcriptional coactivator TAZ regulates mesenchymal differentiation in malignant glioma. Genes \& development 25 (24):2594-2609. doi:10.1101/gad.176800.111

14. Bielamowicz K, Khawja S, Ahmed N (2013) Adoptive cell therapies for glioblastoma. Frontiers in oncology 3:275. doi:10.3389/fonc.2013.00275 
15. Blay J, White TD, Hoskin DW (1997) The extracellular fluid of solid carcinomas contains immunosuppressive concentrations of adenosine. Cancer research 57 (13):2602-2605

16. Boche D, Perry VH, Nicoll JA (2013) Review: activation patterns of microglia and their identification in the human brain. Neuropathology and applied neurobiology 39 (1):3-18. doi:10.1111/nan.12011

17. Bradley D, Rees J (2013) Updates in the management of high-grade glioma. Journal of neurology. doi:10.1007/s00415-013-7032-x

18. Brantley EC, Benveniste EN (2008) Signal transducer and activator of transcription3: a molecular hub for signaling pathways in gliomas. Molecular cancer research : MCR 6 (5):675-684. doi:10.1158/1541-7786.MCR-07-2180

19. Brennan CW, Verhaak RG, McKenna A, Campos B, Noushmehr H, Salama SR, Zheng S, Chakravarty D, Sanborn JZ, Berman SH, Beroukhim R, Bernard B, Wu CJ, Genovese G, Shmulevich I, Barnholtz-Sloan J, Zou L, Vegesna R, Shukla SA, Ciriello G, Yung WK, Zhang W, Sougnez C, Mikkelsen T, Aldape K, Bigner DD, Van Meir EG, Prados M, Sloan A, Black KL, Eschbacher J, Finocchiaro G, Friedman W, Andrews DW, Guha A, Iacocca M, O'Neill BP, Foltz G, Myers J, Weisenberger DJ, Penny R, Kucherlapati R, Perou CM, Hayes DN, Gibbs R, Marra M, Mills GB, Lander E, Spellman P, Wilson R, Sander C, Weinstein J, Meyerson M, Gabriel S, Laird PW, Haussler D, Getz G, Chin L, Network TR (2013) The somatic genomic landscape of glioblastoma. Cell 155 (2):462-477. doi:10.1016/j.cell.2013.09.034

20. Butovsky O, Jedrychowski MP, Moore CS, Cialic R, Lanser AJ, Gabriely G, Koeglsperger T, Dake B, Wu PM, Doykan CE, Fanek Z, Liu L, Chen Z, Rothstein JD, Ransohoff RM, Gygi SP, Antel JP, Weiner HL (2014) Identification of a unique TGF-beta-dependent molecular and functional signature in microglia. Nature neuroscience 17 (1):131-143. doi:10.1038/nn.3599 
21. Carro MS, Lim WK, Alvarez MJ, Bollo RJ, Zhao X, Snyder EY, Sulman EP, Anne SL, Doetsch F, Colman H, Lasorella A, Aldape K, Califano A, Iavarone A (2010) The transcriptional network for mesenchymal transformation of brain tumours. Nature 463 (7279):318-325. doi:10.1038/nature08712

22. Casazza A, Laoui D, Wenes M, Rizzolio S, Bassani N, Mambretti M, Deschoemaeker S, Van Ginderachter JA, Tamagnone L, Mazzone M (2013) Impeding Macrophage Entry into Hypoxic Tumor Areas by Sema3A/Nrp1 Signaling Blockade Inhibits Angiogenesis and Restores Antitumor Immunity. Cancer Cell 24 (6):695-709. doi:10.1016/j.ccr.2013.11.007

23. Chen J, McKay RM, Parada LF (2012) Malignant glioma: lessons from genomics, mouse models, and stem cells. Cell 149 (1):36-47. doi:10.1016/j.cell.2012.03.009

24. Ciechomska IA, Gabrusiewicz K, Szczepankiewicz AA, Kaminska B (2013) Endoplasmic reticulum stress triggers autophagy in malignant glioma cells undergoing cyclosporine a-induced cell death. Oncogene 32 (12):1518-1529. doi:10.1038/onc.2012.174

25. Compton JJ, Laack NN, Eckel LJ, Schomas DA, Giannini C, Meyer FB (2012) Longterm outcomes for low-grade intracranial ganglioglioma: 30-year experience from $\begin{array}{lllll}\text { the Mayo Clinic. Journal of neurosurgery } 117 & \text { (5):825-830. }\end{array}$ doi:10.3171/2012.7.JNS111260

26. Coniglio SJ, Eugenin E, Dobrenis K, Stanley ER, West BL, Symons MH, Segall JE (2012) Microglial stimulation of glioblastoma invasion involves epidermal growth factor receptor (EGFR) and colony stimulating factor 1 receptor (CSF-1R) signaling. Mol Med 18:519-527. doi:10.2119/molmed.2011.00217

27. Cooper LA, Gutman DA, Chisolm C, Appin C, Kong J, Rong Y, Kurc T, Van Meir EG, Saltz JH, Moreno CS, Brat DJ (2012) The tumor microenvironment strongly impacts master transcriptional regulators and gene expression class of glioblastoma. The American journal of pathology 180 (5):2108-2119. doi:10.1016/j.ajpath.2012.01.040 
28. Csoka B, Selmeczy Z, Koscso B, Nemeth ZH, Pacher P, Murray PJ, Kepka-Lenhart D, Morris SM, Jr., Gause WC, Leibovich SJ, Hasko G (2012) Adenosine promotes alternative macrophage activation via A2A and A2B receptors. FASEB journal : official publication of the Federation of American Societies for Experimental Biology 26 (1):376-386. doi:10.1096/fj.11-190934

29. Cunningham CL, Martinez-Cerdeno V, Noctor SC (2013) Microglia regulate the number of neural precursor cells in the developing cerebral cortex. The Journal of neuroscience : the official journal of the Society for Neuroscience 33 (10):42164233. doi:10.1523/JNEUROSCI.3441-12.2013

30. Davalos D, Grutzendler J, Yang G, Kim JV, Zuo Y, Jung S, Littman DR, Dustin ML, Gan WB (2005) ATP mediates rapid microglial response to local brain injury in vivo. Nature neuroscience 8 (6):752-758. doi:10.1038/nn1472

31. del Río-Hortega P (1921) Sobre la fagocitosis en los tumores y en otros procesos patológicos. In: Río-Hortega Pd (ed) Archivos de Cardiología y Hematología, vol 2. pp $161-220$

32. Diserbo M, Agin A, Lamproglou I, Mauris J, Staali F, Multon E, Amourette C (2002) Blood-brain barrier permeability after gamma whole-body irradiation: an in vivo microdialysis study. Canadian journal of physiology and pharmacology 80 (7):670-678

33. Dityatev A, Seidenbecher CI, Schachner M (2010) Compartmentalization from the outside: the extracellular matrix and functional microdomains in the brain. Trends in neurosciences 33 (11):503-512. doi:10.1016/j.tins.2010.08.003

34. Doucette T, Rao G, Rao A, Shen L, Aldape K, Wei J, Dziurzynski K, Gilbert M, Heimberger AB (2013) Immune Heterogeneity of Glioblastoma Subtypes: Extrapolation from the Cancer Genome Atlas. Cancer immunology research 1 (112). doi:10.1158/2326-6066.CIR-13-0028 
35. Ebert S, Gerber J, Bader S, Muhlhauser F, Brechtel K, Mitchell TJ, Nau R (2005) Dose-dependent activation of microglial cells by Toll-like receptor agonists alone and in combination. Journal of neuroimmunology 159 (1-2):87-96. doi:10.1016/j.jneuroim.2004.10.005

36. El Andaloussi A, Sonabend AM, Han Y, Lesniak MS (2006) Stimulation of TLR9 with CpG ODN enhances apoptosis of glioma and prolongs the survival of mice with experimental brain tumors. Glia 54 (6):526-535. doi:10.1002/glia.20401

37. Ellert-Miklaszewska A, Dabrowski M, Lipko M, Sliwa M, Maleszewska M, Kaminska B (2013) Molecular definition of the pro-tumorigenic phenotype of glioma-activated microglia. Glia 61 (7):1178-1190. doi:10.1002/glia.22510

38. Engler JR, Robinson AE, Smirnov I, Hodgson JG, Berger MS, Gupta N, James CD, Molinaro A, Phillips JJ (2012) Increased microglia/macrophage gene expression in a subset of adult and pediatric astrocytomas. PloS one 7 (8):e43339. doi:10.1371/journal.pone.0043339

39. Flugel A, Labeur MS, Grasbon-Frodl EM, Kreutzberg GW, Graeber MB (1999) Microglia only weakly present glioma antigen to cytotoxic $T$ cells. International journal of developmental neuroscience : the official journal of the International Society for Developmental Neuroscience 17 (5-6):547-556

40. Franke H, Verkhratsky A, Burnstock G, Illes P (2012) Pathophysiology of astroglial purinergic signalling. Purinergic signalling 8 (3):629-657. doi:10.1007/s11302012-9300-0

41. Friedmann-Morvinski D, Bushong EA, Ke E, Soda Y, Marumoto T, Singer O, Ellisman MH, Verma IM (2012) Dedifferentiation of neurons and astrocytes by oncogenes can induce gliomas in mice. Science 338 (6110):1080-1084. doi:10.1126/science.1226929

42. Gabrusiewicz K, Ellert-Miklaszewska A, Lipko M, Sielska M, Frankowska M, Kaminska B (2011) Characteristics of the alternative phenotype of 
microglia/macrophages and its modulation in experimental gliomas. PloS one 6 (8):e23902. doi:10.1371/journal.pone.0023902

43. Galarneau H, Villeneuve J, Gowing G, Julien JP, Vallieres L (2007) Increased glioma growth in mice depleted of macrophages. Cancer research 67 (18):8874-8881. doi:67/18/8874 [pii]

10.1158/0008-5472.CAN-07-0177

44. Ginhoux F, Greter M, Leboeuf M, Nandi S, See P, Gokhan S, Mehler MF, Conway SJ, Ng LG, Stanley ER, Samokhvalov IM, Merad M (2010) Fate mapping analysis reveals that adult microglia derive from primitive macrophages. Science 330 (6005):841-845. doi:10.1126/science.1194637

45. Goldmann T, Wieghofer P, Muller PF, Wolf Y, Varol D, Yona S, Brendecke SM, Kierdorf K, Staszewski O, Datta M, Luedde T, Heikenwalder M, Jung S, Prinz M (2013) A new type of microglia gene targeting shows TAK1 to be pivotal in CNS autoimmune inflammation. Nature neuroscience 16 (11):1618-1626. doi:10.1038/nn.3531

46. Gomez Perdiguero E, Schulz C, Geissmann F (2013) Development and homeostasis of "resident" myeloid cells: The case of the microglia. Glia 61 (1):112-120. doi:10.1002/glia.22393

47. Graeber MB, Scheithauer BW, Kreutzberg GW (2002) Microglia in brain tumors. Glia 40 (2):252-259

48. Grauer OM, Molling JW, Bennink E, Toonen LW, Sutmuller RP, Nierkens S, Adema GJ (2008) TLR ligands in the local treatment of established intracerebral murine gliomas. J Immunol 181 (10):6720-6729

49. Hanisch UK (2013) Proteins in microglial activation--inputs and outputs by subsets. Current protein \& peptide science 14 (1):3-15 
50. Hanisch UK, Kettenmann H (2007) Microglia: active sensor and versatile effector cells in the normal and pathologic brain. Nature neuroscience 10 (11):1387-1394. doi:nn1997 [pii]

10.1038/nn1997

51. Harrison JK, Jiang Y, Chen S, Xia Y, Maciejewski D, McNamara RK, Streit WJ, Salafranca MN, Adhikari S, Thompson DA, Botti P, Bacon KB, Feng L (1998) Role for neuronally derived fractalkine in mediating interactions between neurons and CX3CR1-expressing microglia. Proceedings of the National Academy of Sciences of the United States of America 95 (18):10896-10901

52. Hart AD, Wyttenbach A, Perry VH, Teeling JL (2012) Age related changes in microglial phenotype vary between CNS regions: grey versus white matter differences. Brain, behavior, and immunity 26 (5):754-765. doi:10.1016/j.bbi.2011.11.006

53. Hasko G, Cronstein BN (2004) Adenosine: an endogenous regulator of innate immunity. Trends in immunology 25 (1):33-39

54. Hegi ME, Diserens AC, Gorlia T, Hamou MF, de Tribolet N, Weller M, Kros JM, Hainfellner JA, Mason W, Mariani L, Bromberg JE, Hau P, Mirimanoff RO, Cairncross JG, Janzer RC, Stupp R (2005) MGMT gene silencing and benefit from temozolomide in glioblastoma. The New England journal of medicine 352 (10):997-1003. doi:10.1056/NEJMoa043331

55. Heimberger AB, Sampson JH (2011) Immunotherapy coming of age: what will it take to make it standard of care for glioblastoma? Neuro-oncology 13 (1):3-13. doi:10.1093/neuonc/noq169

56. Held-Feindt J, Hattermann K, Muerkoster SS, Wedderkopp H, Knerlich-Lukoschus F, Ungefroren H, Mehdorn HM, Mentlein R (2010) CX3CR1 promotes recruitment of human glioma-infiltrating microglia/macrophages (GIMs). Experimental cell research 316 (9):1553-1566. doi:10.1016/j.yexcr.2010.02.018 
57. Herculano-Houzel S (2009) The human brain in numbers: a linearly scaled-up primate brain. Frontiers in human neuroscience 3:31. doi:10.3389/neuro.09.031.2009

58. Hickman SE, Kingery ND, Ohsumi TK, Borowsky ML, Wang LC, Means TK, El Khoury J (2013) The microglial sensome revealed by direct RNA sequencing. Nature neuroscience 16 (12):1896-1905. doi:10.1038/nn.3554

59. Hussain SF, Kong LY, Jordan J, Conrad C, Madden T, Fokt I, Priebe W, Heimberger AB (2007) A novel small molecule inhibitor of signal transducers and activators of transcription 3 reverses immune tolerance in malignant glioma patients. Cancer research 67 (20):9630-9636. doi:10.1158/0008-5472.CAN-07-1243

60. Hussain SF, Yang D, Suki D, Aldape K, Grimm E, Heimberger AB (2006) The role of human glioma-infiltrating microglia/macrophages in mediating antitumor immune responses. Neuro-oncology 8 (3):261-279. doi:10.1215/15228517-2006008

61. Ishihara H, Kubota H, Lindberg RL, Leppert D, Gloor SM, Errede M, Virgintino D, Fontana A, Yonekawa Y, Frei K (2008) Endothelial cell barrier impairment induced by glioblastomas and transforming growth factor beta2 involves matrix metalloproteinases and tight junction proteins. Journal of neuropathology and experimental neurology 67 (5):435-448. doi:10.1097/NEN.0b013e31816fd622

62. Jack CS, Arbour N, Manusow J, Montgrain V, Blain M, McCrea E, Shapiro A, Antel JP (2005) TLR signaling tailors innate immune responses in human microglia and astrocytes. J Immunol 175 (7):4320-4330

63. Jacobs VL, Landry RP, Liu Y, Romero-Sandoval EA, De Leo JA (2012) Propentofylline decreases tumor growth in a rodent model of glioblastoma multiforme by a direct mechanism on microglia. Neuro-oncology 14 (2):119-131. doi:10.1093/neuonc/nor194 
64. Janicki CN, Jenkinson SR, Williams NA, Morgan DJ (2008) Loss of CTL function among high-avidity tumor-specific CD8+ $\mathrm{T}$ cells following tumor infiltration. Cancer research 68 (8):2993-3000. doi:10.1158/0008-5472.CAN-07-5008

65. Jansen T, Tyler B, Mankowski JL, Recinos VR, Pradilla G, Legnani F, Laterra J, Olivi A (2010) FasL gene knock-down therapy enhances the antiglioma immune response. Neuro-oncology 12 (5):482-489. doi:10.1093/neuonc/nop052

66. Jantaratnotai N, Choi HB, McLarnon JG (2009) ATP stimulates chemokine production via a store-operated calcium entry pathway in C6 glioma cells. BMC cancer 9:442. doi:10.1186/1471-2407-9-442

67. Joseph J, Knobler RL, D'Imperio C, Lublin FD (1988) Down-regulation of interferongamma-induced class II expression on human glioma cells by recombinant interferon-beta: effects of dosage treatment schedule. Journal of neuroimmunology 20 (1):39-44

68. Kaminska B, Kocyk M, Kijewska M (2013) TGF beta signaling and its role in glioma pathogenesis. Advances in experimental medicine and biology 986:171-187. doi:10.1007/978-94-007-4719-7_9

69. Kaneko YS, Ota A, Nakashima A, Mori K, Nagatsu I, Nagatsu T (2012) Regulation of oxidative stress in long-lived lipopolysaccharide-activated microglia. Clinical and experimental pharmacology \& physiology 39 (7):599-607. doi:10.1111/j.1440-1681.2012.05716.x

70. Kees T, Lohr J, Noack J, Mora R, Gdynia G, Todt G, Ernst A, Radlwimmer B, Falk CS, Herold-Mende C, Regnier-Vigouroux A (2012) Microglia isolated from patients with glioma gain antitumor activities on poly (I:C) stimulation. Neurooncology 14 (1):64-78. doi:10.1093/neuonc/nor182

71. Kettenmann H, Hanisch UK, Noda M, Verkhratsky A (2011) Physiology of $\begin{array}{lllll}\text { microglia. } & \text { Physiological } & \text { reviews } & 91 & \text { (2):461-553. }\end{array}$ doi:10.1152/physrev.00011.2010 
72. Kettenmann H, Kirchhoff F, Verkhratsky A (2013) Microglia: new roles for the synaptic stripper. Neuron 77 (1):10-18. doi:10.1016/j.neuron.2012.12.023

73. Kierdorf K, Erny D, Goldmann T, Sander V, Schulz C, Perdiguero EG, Wieghofer P, Heinrich A, Riemke P, Holscher C, Muller DN, Luckow B, Brocker T, Debowski K, Fritz G, Opdenakker G, Diefenbach A, Biber K, Heikenwalder M, Geissmann F, Rosenbauer F, Prinz M (2013) Microglia emerge from erythromyeloid precursors via Pu.1- and Irf8-dependent pathways. Nature neuroscience 16 (3):273-280. doi:10.1038/nn.3318

74. Kim J, Hajjar KA (2002) Annexin II: a plasminogen-plasminogen activator coreceptor. Frontiers in bioscience : a journal and virtual library 7:d341-348

75. Kleihues PB, P.C.; Scheithauer, B.W. (1996) Histological typing of the tumours of the central nervous system. International histological classification of tumours, 2nd edn. Springer, Stuttgart

76. Kloss CU, Bohatschek M, Kreutzberg GW, Raivich G (2001) Effect of lipopolysaccharide on the morphology and integrin immunoreactivity of ramified microglia in the mouse brain and in cell culture. Experimental neurology 168 (1):32-46. doi:10.1006/exnr.2000.7575

77. Kobayashi K, Imagama S, Ohgomori T, Hirano K, Uchimura K, Sakamoto K, Hirakawa A, Takeuchi H, Suzumura A, Ishiguro N, Kadomatsu K (2013) Minocycline selectively inhibits M1 polarization of microglia. Cell death \& disease 4:e525. doi:10.1038/cddis.2013.54

78. Komohara Y, Ohnishi K, Kuratsu J, Takeya M (2008) Possible involvement of the M2 anti-inflammatory macrophage phenotype in growth of human gliomas. The Journal of pathology 216 (1):15-24. doi:10.1002/path.2370

79. Kortylewski M, Kujawski M, Wang T, Wei S, Zhang S, Pilon-Thomas S, Niu G, Kay H, Mule J, Kerr WG, Jove R, Pardoll D, Yu H (2005) Inhibiting Stat3 signaling in 
the hematopoietic system elicits multicomponent antitumor immunity. Nat Med 11 (12):1314-1321. doi:10.1038/nm1325

80. Ku MC, Wolf SA, Respondek D, Matyash V, Pohlmann A, Waiczies S, Waiczies H, Niendorf T, Synowitz M, Glass R, Kettenmann H (2013) GDNF mediates glioblastoma-induced microglia attraction but not astrogliosis. Acta neuropathologica 125 (4):609-620. doi:10.1007/s00401-013-1079-8

81. Kurpad SN, Wikstrand CJ, Bigner DD (1994) Immunobiology of malignant astrocytomas. Seminars in oncology 21 (2):149-161

82. Lakka SS, Gondi CS, Rao JS (2005) Proteases and glioma angiogenesis. Brain Pathol 15 (4):327-341

83. Lawson LJ, Perry VH, Dri P, Gordon S (1990) Heterogeneity in the distribution and morphology of microglia in the normal adult mouse brain. Neuroscience 39 (1):151-170

84. Li B, Senbabaoglu Y, Peng W, Yang ML, Xu J, Li JZ (2012) Genomic estimates of aneuploid content in glioblastoma multiforme and improved classification. Clinical cancer research : an official journal of the American Association for Cancer Research 18 (20):5595-5605. doi:10.1158/1078-0432.CCR-12-1427

85. Linden J (2006) Adenosine metabolism and cancer. Focus on "Adenosine downregulates DPPIV on HT-29 colon cancer cells by stimulating protein tyrosine phosphatases and reducing ERK1/2 activity via a novel pathway". American journal of physiology Cell physiology 291 (3):C405-406. doi:10.1152/ajpcell.00242.2006

86. Liu C, Luo D, Streit WJ, Harrison JK (2008) CX3CL1 and CX3CR1 in the GL261 murine model of glioma: CX3CR1 deficiency does not impact tumor growth or infiltration of microglia and lymphocytes. Journal of neuroimmunology 198 (12):98-105. doi:10.1016/j.jneuroim.2008.04.016 
87. Louis DN, Ohgaki H, Wiestler OD, Cavenee WK, Burger PC, Jouvet A, Scheithauer BW, Kleihues P (2007) The 2007 WHO classification of tumours of the central nervous system. Acta neuropathologica 114 (2):97-109. doi:10.1007/s00401-0070243-4

88. Luongo L, Guida F, Imperatore R, Napolitano F, Gatta L, Cristino L, Giordano C, Siniscalco D, Di Marzo V, Bellini G, Petrelli R, Cappellacci L, Usiello A, de Novellis V, Rossi F, Maione S (2014) The A1 adenosine receptor as a new player in microglia physiology. Glia 62 (1):122-132. doi:10.1002/glia.22592

89. Machein MR, Renninger S, de Lima-Hahn E, Plate KH (2003) Minor contribution of bone marrow-derived endothelial progenitors to the vascularization of murine gliomas. Brain Pathol 13 (4):582-597

90. Mark R. Gilbert JD, Minhee Won, Deborah T. Blumenthal, Michael A. Vogelbaum, Kenneth D. Aldape, Howard Colman, Arnab Chakravarti, Robert Jeraj, Terri S. Armstrong, Jeffrey Scott Wefel, Paul D. Brown, Kurt A. Jaeckle, David Schiff, James Norman Atkins, David Brachman, Maria Werner-Wasik, Ritsuko Komaki, Erik P. Sulman, Minesh P. Mehta; University of Texas MD Anderson Cancer Center Department of Neuro-Oncology, Houston, TX; Radiation Therapy Oncology Group, Philadelphia, PA; Tel Aviv Sourasky Medical Center, Tel Aviv, Israel; Cleveland Clinic Foundation, Cleveland, OH; The University of Texas MD Anderson Cancer Center, Houston, TX; University of Utah, Huntsman Cancer Institute, Salt Lake City, UT; Arthur G. James Cancer Center, The Ohio State University, Columbus, OH; Department of Medical Physics, University of Wisconsin, Madison, WI; University of Texas Health Science Center School of Nursing, Houston, TX; Mayo Clinic, Jacksonville, FL; University of Virginia Medical Center, Charlottesville, VA; National Surgical Adjuvant Breast and Bowel Project and SCCC-CCOP, Goldboro, NC; Arizona Oncology Services Foundation, Phoenix, AZ; Thomas Jefferson University Hospital, Philadelphia, PA; University of Maryland, Baltimore, MD (2013) RTOG 0825: Phase III 
double-blind, placebo-controlled trial evaluating bevacizumab in patiens with newly diagnosed glioblastoma. Paper presented at the ASCO Annual Meeting

91. Markovic DS, Glass R, Synowitz M, Rooijen N, Kettenmann H (2005) Microglia stimulate the invasiveness of glioma cells by increasing the activity of metalloprotease-2. Journal of neuropathology and experimental neurology 64 (9):754-762

92. Markovic DS, Vinnakota K, Chirasani S, Synowitz M, Raguet H, Stock K, Sliwa M, Lehmann S, Kalin R, van Rooijen N, Holmbeck K, Heppner FL, Kiwit J, Matyash V, Lehnardt S, Kaminska B, Glass R, Kettenmann H (2009) Gliomas induce and exploit microglial MT1-MMP expression for tumor expansion. Proceedings of the National Academy of Sciences of the United States of America 106 (30):1253012535. doi:10.1073/pnas.0804273106

93. Markovic DS, Vinnakota K, van Rooijen N, Kiwit J, Synowitz M, Glass R, Kettenmann H (2011) Minocycline reduces glioma expansion and invasion by attenuating microglial MT1-MMP expression. Brain, behavior, and immunity 25 (4):624-628. doi:10.1016/j.bbi.2011.01.015

94. Mildner A, Schmidt H, Nitsche M, Merkler D, Hanisch UK, Mack M, Heikenwalder M, Bruck W, Priller J, Prinz M (2007) Microglia in the adult brain arise from Ly6ChiCCR2+ monocytes only under defined host conditions. Nature neuroscience 10 (12):1544-1553. doi:10.1038/nn2015

95. Morioka T, Baba T, Black KL, Streit WJ (1992) Response of microglial cells to experimental rat glioma. Glia 6 (1):75-79. doi:10.1002/glia.440060110

96. Mosieniak G, Figiel I, Kaminska B (1997) Cyclosporin A, an immunosuppressive drug, induces programmed cell death in rat C6 glioma cells by a mechanism that involves the AP-1 transcription factor. Journal of neurochemistry 68 (3):11421149 
97. Naganuma H, Sasaki A, Satoh E, Nagasaka M, Nakano S, Isoe S, Nukui H (1998) Down-regulation of transforming growth factor-beta and interleukin-10 secretion from malignant glioma cells by cytokines and anticancer drugs. Journal of neurooncology 39 (3):227-236

98. Nakano Y, Kuroda E, Kito T, Uematsu S, Akira S, Yokota A, Nishizawa S, Yamashita U (2008) Induction of prostaglandin E2 synthesis and microsomal prostaglandin E synthase-1 expression in murine microglia by glioma-derived soluble factors. Laboratory investigation. Journal of neurosurgery 108 (2):311319. doi:10.3171/JNS/2008/108/2/0311

99. Nieto MA (2011) The ins and outs of the epithelial to mesenchymal transition in health and disease. Annual review of cell and developmental biology 27:347-376. doi:10.1146/annurev-cellbio-092910-154036

100. Nimmerjahn A, Kirchhoff F, Helmchen F (2005) Resting microglial cells are highly dynamic surveillants of brain parenchyma in vivo. Science 308 (5726):13141318. doi:1110647 [pii]

10.1126/science. 1110647

101. Nishie A, Ono M, Shono T, Fukushi J, Otsubo M, Onoue H, Ito Y, Inamura T, Ikezaki K, Fukui M, Iwaki T, Kuwano M (1999) Macrophage infiltration and heme oxygenase-1 expression correlate with angiogenesis in human gliomas. Clinical cancer research : an official journal of the American Association for Cancer Research 5 (5):1107-1113

102. Norden AD, Drappatz J, Wen PY (2009) Antiangiogenic therapies for high-grade glioma. Nat Rev Neurol 5 (11):610-620. doi:10.1038/nrneurol.2009.159

103. Ohgaki H, Kleihues P (2007) Genetic pathways to primary and secondary glioblastoma. The American journal of pathology 170 (5):1445-1453 
104. Ohnishi T, Matsumura H, Izumoto S, Hiraga S, Hayakawa T (1998) A novel model of glioma cell invasion using organotypic brain slice culture. Cancer research 58 (14):2935-2940

105. Okada M, Saio M, Kito Y, Ohe N, Yano H, Yoshimura S, Iwama T, Takami T (2009) Tumor-associated macrophage/microglia infiltration in human gliomas is correlated with MCP-3, but not MCP-1. International journal of oncology 34 (6):1621-1627

106. Omuro A, DeAngelis LM (2013) Glioblastoma and other malignant gliomas: a clinical review. JAMA : the journal of the American Medical Association 310 (17):1842-1850. doi:10.1001/jama.2013.280319

107. Ostrom QT, Gittleman H, Farah P, Ondracek A, Chen Y, Wolinsky Y, Stroup NE, Kruchko C, Barnholtz-Sloan JS (2013) CBTRUS statistical report: Primary brain and central nervous system tumors diagnosed in the United States in 2006-2010. Neuro-oncology 15 Suppl 2:ii1-56. doi:10.1093/neuonc/not151

108. Pagano M, Reboud-Ravaux M (2011) Cryptic activities of fibronectin fragments, particularly cryptic proteases. Front Biosci (Landmark Ed) 16:698-706

109. Paolicelli RC, Gross CT (2011) Microglia in development: linking brain wiring to brain environment. Neuron glia biology 7 (1):77-83. doi:10.1017/S1740925X12000105

110. Parney IF, Waldron JS, Parsa AT (2009) Flow cytometry and in vitro analysis of human glioma-associated macrophages. Laboratory investigation. Journal of neurosurgery 110 (3):572-582. doi:10.3171/2008.7.JNS08475

111. Penfield W (1925) Microglia and the Process of Phagocytosis in Gliomas. The American journal of pathology 1 (1):77-90 15

112. Penuelas S, Anido J, Prieto-Sanchez RM, Folch G, Barba I, Cuartas I, GarciaDorado D, Poca MA, Sahuquillo J, Baselga J, Seoane J (2009) TGF-beta increases glioma-initiating cell self-renewal through the induction of LIF in 
human glioblastoma. Cancer Cell 15 (4):315-327. doi:S1535-6108(09)00042-7 [pii]

10.1016/j.ccr.2009.02.011

113. Phillips HS, Kharbanda S, Chen R, Forrest WF, Soriano RH, Wu TD, Misra A, Nigro JM, Colman H, Soroceanu L, Williams PM, Modrusan Z, Feuerstein BG, Aldape K (2006) Molecular subclasses of high-grade glioma predict prognosis, delineate a pattern of disease progression, and resemble stages in neurogenesis. Cancer Cell 9 (3):157-173

114. Piao Y, Liang J, Holmes L, Henry V, Sulman E, de Groot JF (2013) Acquired resistance to anti-VEGF therapy in glioblastoma is associated with a mesenchymal transition. Clinical cancer research : an official journal of the American Association for Cancer Research 19 (16):4392-4403. doi:10.1158/1078-0432.CCR-12-1557

115. Piao Y, Liang J, Holmes L, Zurita AJ, Henry V, Heymach JV, de Groot JF (2012) Glioblastoma resistance to anti-VEGF therapy is associated with myeloid cell infiltration, stem cell accumulation, and a mesenchymal phenotype. Neurooncology 14 (11):1379-1392. doi:10.1093/neuonc/nos158

116. Platten M, Kretz A, Naumann U, Aulwurm S, Egashira K, Isenmann S, Weller M (2003) Monocyte chemoattractant protein-1 increases microglial infiltration and aggressiveness of gliomas. Ann Neurol 54 (3):388-392

117. Priller J, Flugel A, Wehner T, Boentert M, Haas CA, Prinz M, Fernandez-Klett F, Prass K, Bechmann I, de Boer BA, Frotscher M, Kreutzberg GW, Persons DA, Dirnagl U (2001) Targeting gene-modified hematopoietic cells to the central nervous system: use of green fluorescent protein uncovers microglial engraftment. Nat Med 7 (12):1356-1361. doi:10.1038/nm1201-1356

118. Pyonteck SM, Akkari L, Schuhmacher AJ, Bowman RL, Sevenich L, Quail DF, Olson OC, Quick ML, Huse JT, Teijeiro V, Setty M, Leslie CS, Oei Y, Pedraza A, Zhang J, Brennan CW, Sutton JC, Holland EC, Daniel D, Joyce JA (2013) 
CSF-1R inhibition alters macrophage polarization and blocks glioma progression. Nat Med 19 (10):1264-1272. doi:10.1038/nm.3337

119. Qian BZ, Pollard JW (2010) Macrophage diversity enhances tumor progression and metastasis. Cell 141 (1):39-51. doi:10.1016/j.cell.2010.03.014

120. Qin H, Yeh WI, De Sarno P, Holdbrooks AT, Liu Y, Muldowney MT, Reynolds SL, Yanagisawa LL, Fox TH, 3rd, Park K, Harrington LE, Raman C, Benveniste EN (2012) Signal transducer and activator of transcription-3/suppressor of cytokine signaling-3 (STAT3/SOCS3) axis in myeloid cells regulates neuroinflammation. Proceedings of the National Academy of Sciences of the United States of America 109 (13):5004-5009. doi:10.1073/pnas.1117218109

121. Raivich G (2005) Like cops on the beat: the active role of resting microglia. Trends in neurosciences 28 (11):571-573. doi:10.1016/j.tins.2005.09.001

122. Ramanathan M, Pinhal-Enfield G, Hao I, Leibovich SJ (2007) Synergistic upregulation of vascular endothelial growth factor (VEGF) expression in macrophages by adenosine A2A receptor agonists and endotoxin involves transcriptional regulation via the hypoxia response element in the VEGF promoter. Molecular biology of the cell 18 (1):14-23. doi:10.1091/mbc.E06-070596

123. Ransohoff RM, Engelhardt B (2012) The anatomical and cellular basis of immune surveillance in the central nervous system. Nature reviews Immunology 12 (9):623-635. doi:10.1038/nri3265

124. Ribes S, Adam N, Schutze S, Regen T, Redlich S, Janova H, Borisch A, Hanisch UK, Nau R (2012) The nucleotide-binding oligomerization domain-containing-2 ligand muramyl dipeptide enhances phagocytosis and intracellular killing of Escherichia coli K1 by Toll-like receptor agonists in microglial cells. Journal of neuroimmunology 252 (1-2):16-23. doi:10.1016/j.jneuroim.2012.07.012 
125. Roggendorf W, Strupp S, Paulus W (1996) Distribution and characterization of microglia/macrophages in human brain tumors. Acta Neuropathol (Berl) 92 (3):288-293

126. Rolle CE, Sengupta S, Lesniak MS (2012) Mechanisms of immune evasion by gliomas. Advances in experimental medicine and biology 746:53-76. doi:10.1007/978-1-4614-3146-6_5

127. Rutka JT, Apodaca G, Stern R, Rosenblum M (1988) The extracellular matrix of the central and peripheral nervous systems: structure and function. Journal of neurosurgery 69 (2):155-170. doi:10.3171/jns.1988.69.2.0155

128. Sahm F, Oezen I, Opitz CA, Radlwimmer B, von Deimling A, Ahrendt T, Adams S, Bode HB, Guillemin GJ, Wick W, Platten M (2013) The endogenous tryptophan metabolite and NAD+ precursor quinolinic acid confers resistance of gliomas to oxidative stress. Cancer research 73 (11):3225-3234. doi:10.1158/00085472.CAN-12-3831

129. Saijo K, Glass CK (2011) Microglial cell origin and phenotypes in health and disease. Nature reviews Immunology 11 (11):775-787. doi:10.1038/nri3086

130. Sanai N, Berger MS (2012) Recent surgical management of gliomas. Advances in experimental medicine and biology 746:12-25. doi:10.1007/978-1-4614-3146-6_2

131. Sarkar S, Doring A, Zemp FJ, Silva C, Lun X, Wang X, Kelly J, Hader W, Hamilton M, Mercier P, Dunn JF, Kinniburgh D, van Rooijen N, Robbins S, Forsyth P, Cairncross G, Weiss S, Yong VW (2014) Therapeutic activation of macrophages and microglia to suppress brain tumor-initiating cells. Nature neuroscience 17 (1):46-55. doi:10.1038/nn.3597

132. Schartner JM, Hagar AR, Van Handel M, Zhang L, Nadkarni N, Badie B (2005) Impaired capacity for upregulation of MHC class II in tumor-associated microglia. Glia 51 (4):279-285. doi:10.1002/glia.20201 
133. Schulz C, Gomez Perdiguero E, Chorro L, Szabo-Rogers H, Cagnard N, Kierdorf K, Prinz M, Wu B, Jacobsen SE, Pollard JW, Frampton J, Liu KJ, Geissmann F (2012) A lineage of myeloid cells independent of Myb and hematopoietic stem cells. Science 336 (6077):86-90. doi:10.1126/science.1219179

134. Schwaighofer H, Kernan NA, O'Reilly RJ, Brankova J, Nachbaur D, Herold M, Eibl B, Niederwieser D (1996) Serum levels of cytokines and secondary messages after T-cell-depleted and non-T-cell-depleted bone marrow transplantation: influence of conditioning and hematopoietic reconstitution. Transplantation 62 (7):947-953

135. Seiki M (2003) Membrane-type 1 matrix metalloproteinase: a key enzyme for tumor invasion. Cancer Lett 194 (1):1-11. doi:S0304383502006997 [pii]

136. Sengupta S, Marrinan J, Frishman C, Sampath P (2012) Impact of temozolomide on immune response during malignant glioma chemotherapy. Clinical \& developmental immunology 2012:831090. doi:10.1155/2012/831090

137. Shechter R, Schwartz M (2013) Harnessing monocyte-derived macrophages to control central nervous system pathologies: no longer 'if' but 'how'. The Journal of pathology 229 (2):332-346. doi:10.1002/path.4106

138. Shinonaga M, Chang CC, Suzuki N, Sato M, Kuwabara T (1988) Immunohistological evaluation of macrophage infiltrates in brain tumors. Correlation with peritumoral edema. Journal of neurosurgery 68 (2):259-265. doi:10.3171/jns.1988.68.2.0259

139. Sica A, Schioppa T, Mantovani A, Allavena P (2006) Tumour-associated macrophages are a distinct M2 polarised population promoting tumour progression: potential targets of anti-cancer therapy. Eur J Cancer 42 (6):717-727. doi:10.1016/j.ejca.2006.01.003

140. Sielska M, Przanowski P, Wylot B, Gabrusiewicz K, Maleszewska M, Kijewska M, Zawadzka M, Kucharska J, Vinnakota K, Kettenmann H, Kotulska K, 
Grajkowska W, Kaminska B (2013) Distinct roles of CSF family cytokines in macrophage infiltration and activation in glioma progression and injury response. The Journal of pathology 230 (3):310-321. doi:10.1002/path.4192

141. Sliwa M, Markovic D, Gabrusiewicz K, Synowitz M, Glass R, Zawadzka M, Wesolowska A, Kettenmann H, Kaminska B (2007) The invasion promoting effect of microglia on glioblastoma cells is inhibited by cyclosporin A. Brain : a journal of neurology 130 (Pt 2):476-489

142. Sonabend AM, Rolle CE, Lesniak MS (2008) The role of regulatory T cells in malignant glioma. Anticancer research 28 (2B):1143-1150

143. Streit WJ (1994) Cellular immune response in brain tumors. Neuropathology and applied neurobiology 20 (2):205-206

144. Suzumura A, Sawada M, Yamamoto H, Marunouchi T (1993) Transforming growth factor-beta suppresses activation and proliferation of microglia in vitro. J Immunol 151 (4):2150-2158

145. Synowitz M, Glass R, Farber K, Markovic D, Kronenberg G, Herrmann K, Schnermann J, Nolte C, van Rooijen N, Kiwit J, Kettenmann H (2006) A1 adenosine receptors in microglia control glioblastoma-host interaction. Cancer research 66 (17):8550-8557

146. Tabatabai G, Bahr O, Mohle R, Eyupoglu IY, Boehmler AM, Wischhusen J, Rieger J, Blumcke I, Weller M, Wick W (2005) Lessons from the bone marrow: how malignant glioma cells attract adult haematopoietic progenitor cells. Brain : a journal of neurology 128 (Pt 9):2200-2211. doi:10.1093/brain/awh563

147. Tammela T, Zarkada G, Nurmi H, Jakobsson L, Heinolainen K, Tvorogov D, Zheng W, Franco CA, Murtomaki A, Aranda E, Miura N, Yla-Herttuala S, Fruttiger M, Makinen T, Eichmann A, Pollard JW, Gerhardt H, Alitalo K (2011) VEGFR-3 controls tip to stalk conversion at vessel fusion sites by reinforcing Notch signalling. Nat Cell Biol 13 (10):1202-1213. doi:10.1038/ncb2331 
148. Tatter SB (2002) Recurrent malignant glioma in adults. Current treatment options in oncology 3 (6):509-524

149. van Hinsbergh VW, Koolwijk P (2008) Endothelial sprouting and angiogenesis: matrix metalloproteinases in the lead. Cardiovascular research 78 (2):203-212. doi:10.1093/cvr/cvm102

150. Veeravagu A, Jiang B, Ludwig C, Chang SD, Black KL, Patil CG (2013) Biopsy versus resection for the management of low-grade gliomas. The Cochrane database of systematic reviews 4:CD009319. doi:10.1002/14651858.CD009319.pub2

151. Vega EA, Graner MW, Sampson JH (2008) Combating immunosuppression in glioma. Future Oncol 4 (3):433-442. doi:10.2217/14796694.4.3.433

152. Verhaak RG, Hoadley KA, Purdom E, Wang V, Qi Y, Wilkerson MD, Miller CR, Ding L, Golub T, Mesirov JP, Alexe G, Lawrence M, O'Kelly M, Tamayo P, Weir BA, Gabriel S, Winckler W, Gupta S, Jakkula L, Feiler HS, Hodgson JG, James CD, Sarkaria JN, Brennan C, Kahn A, Spellman PT, Wilson RK, Speed TP, Gray JW, Meyerson M, Getz G, Perou CM, Hayes DN (2010) Integrated genomic analysis identifies clinically relevant subtypes of glioblastoma characterized by abnormalities in PDGFRA, IDH1, EGFR, and NF1. Cancer Cell 17 (1):98-110. doi:10.1016/j.ccr.2009.12.020

153. Vince GH, Wagner S, Pietsch T, Klein R, Goldbrunner RH, Roosen K, Tonn JC (1999) Heterogeneous regional expression patterns of matrix metalloproteinases in human malignant gliomas. International journal of developmental neuroscience : the official journal of the International Society for Developmental Neuroscience 17 (5-6):437-445

154. Vinnakota K, Hu F, Ku MC, Georgieva PB, Szulzewsky F, Pohlmann A, Waiczies S, Waiczies H, Niendorf T, Lehnardt S, Hanisch UK, Synowitz M, Markovic D, Wolf SA, Glass R, Kettenmann H (2013) Toll-like receptor 2 mediates 
microglia/brain macrophage MT1-MMP expression and glioma expansion. Neuro-oncology. doi:10.1093/neuonc/not115

155. Visse R, Nagase H (2003) Matrix metalloproteinases and tissue inhibitors of metalloproteinases: structure, function, and biochemistry. Circulation research 92 (8):827-839. doi:10.1161/01.RES.0000070112.80711.3D

156. Vukovic J, Colditz MJ, Blackmore DG, Ruitenberg MJ, Bartlett PF (2012) Microglia modulate hippocampal neural precursor activity in response to exercise and aging. The Journal of neuroscience : the official journal of the Society for Neuroscience 32 (19):6435-6443. doi:10.1523/JNEUROSCI.5925-11.2012

157. Wagner S, Czub S, Greif M, Vince GH, Suss N, Kerkau S, Rieckmann P, Roggendorf W, Roosen K, Tonn JC (1999) Microglial/macrophage expression of interleukin 10 in human glioblastomas. International journal of cancer Journal international du cancer 82 (1):12-16

158. Wainwright DA, Dey M, Chang A, Lesniak MS (2013) Targeting Tregs in Malignant Brain Cancer: Overcoming IDO. Frontiers in immunology 4:116. doi:10.3389/fimmu.2013.00116

159. Walker C, Baborie A, Crooks D, Wilkins S, Jenkinson MD (2011) Biology, genetics and imaging of glial cell tumours. The British journal of radiology 84 Spec No 2:S90-106. doi:10.1259/bjr/23430927

160. Wang SC, Hong JH, Hsueh C, Chiang CS (2012) Tumor-secreted SDF-1 promotes glioma invasiveness and TAM tropism toward hypoxia in a murine astrocytoma model. Laboratory investigation; a journal of technical methods and pathology 92 (1):151-162. doi:10.1038/labinvest.2011.128

161. Watters JJ, Schartner JM, Badie B (2005) Microglia function in brain tumors. Journal of neuroscience research 81 (3):447-455 
162. Wei J, Gabrusiewicz K, Heimberger A (2013) The controversial role of microglia in malignant gliomas. Clinical \& developmental immunology 2013:285246. doi:10.1155/2013/285246

163. Wei J, Wang F, Kong LY, Xu S, Doucette T, Ferguson SD, Yang Y, McEnery K, Jethwa K, Gjyshi O, Qiao W, Levine NB, Lang FF, Rao G, Fuller GN, Calin GA, Heimberger AB (2013) miR-124 inhibits STAT3 signaling to enhance T cellmediated immune clearance of glioma. Cancer research 73 (13):3913-3926. doi:10.1158/0008-5472.CAN-12-4318

164. Wesolowska A, Kwiatkowska A, Slomnicki L, Dembinski M, Master A, Sliwa M, Franciszkiewicz K, Chouaib S, Kaminska B (2008) Microglia-derived TGF-beta as an important regulator of glioblastoma invasion--an inhibition of TGF-betadependent effects by shRNA against human TGF-beta type II receptor. Oncogene 27 (7):918-930. doi:10.1038/sj.onc.1210683

165. Wessels PH, Weber WE, Raven G, Ramaekers FC, Hopman AH, Twijnstra A (2003) Supratentorial grade II astrocytoma: biological features and clinical course. Lancet neurology 2 (7):395-403

166. Wick W, Naumann U, Weller M (2006) Transforming growth factor-beta: a molecular target for the future therapy of glioblastoma. Current pharmaceutical design 12 (3):341-349

167. Ye XZ, Xu SL, Xin YH, Yu SC, Ping YF, Chen L, Xiao HL, Wang B, Yi L, Wang QL, Jiang XF, Yang L, Zhang P, Qian C, Cui YH, Zhang X, Bian XW (2012) Tumor-associated microglia/macrophages enhance the invasion of glioma stemlike cells via TGF-beta1 signaling pathway. J Immunol 189 (1):444-453. doi:10.4049/jimmunol.1103248

168. Yi L, Xiao H, Xu M, Ye X, Hu J, Li F, Li M, Luo C, Yu S, Bian X, Feng H (2011) Glioma-initiating cells: a predominant role in microglia/macrophages tropism to

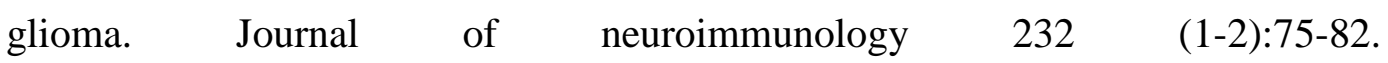
doi:10.1016/j.jneuroim.2010.10.011 
169. Yuan H, Gaber MW, McColgan T, Naimark MD, Kiani MF, Merchant TE (2003) Radiation-induced permeability and leukocyte adhesion in the rat blood-brain barrier: modulation with anti-ICAM-1 antibodies. Brain research 969 (1-2):59-69

170. Zhang L, Alizadeh D, Van Handel M, Kortylewski M, Yu H, Badie B (2009) Stat3 inhibition activates tumor macrophages and abrogates glioma growth in mice. Glia 57 (13):1458-1467. doi:10.1002/glia.20863

171. Zhang L, Handel MV, Schartner JM, Hagar A, Allen G, Curet M, Badie B (2007) Regulation of IL-10 expression by upstream stimulating factor (USF-1) in gliomaassociated microglia. Journal of neuroimmunology 184 (1-2):188-197. doi:10.1016/j.jneuroim.2006.12.006 


\section{Legends}

Figure 1. Myeloid cell polarization in glioma. Glioma-derived factors (black arrow) induce glioma-infiltrating myeloid cells (TAM) to adopt an immune-phenotype that is predominated by markers for the M2-type (alternatively activated), but M1-markers (classically activated) are also present. The M1-shifted TAM mediate anti-tumour effects (e.g. by initiating an adoptive immune response or by releasing cytotoxic oxygen- or nitrogen-radicals) whereas M2-shifted TAM drive tumour-growth, -invasion and angiogenesis (by releasing tumour cell-supporting cytokine, chemokines and angiogenic growth factors). M1- and M2-types are largely controlled by the signal transducer and activator of transcription (STAT) signalling pathways (STAT-1 and STAT-3) and can be induced in microglia and macrophages by different cytokines and growth-factors (blue arrows). Drugs like Amphotericin-B (Amph-B; a clinically approved anti-fungal agent), BLZ945 or PLX3397 (CSFR-1 inhibitors) are able to efficiently modulate gliomapolarized myeloid cells; Amph-B can induce TAM activation (and TAM-mediated tumour stem cell suppression), while CSFR-1 inhibitors block acquisition of the M2 phenotype in TAM.

Figure 2. Glioma chemoattract myeloid cells and induce the a pro-invasive mechanism. Chemoattractants that have been shown to stimulate myeloid cell migration into the gliomas include CSF-1, GDNF, M-CSF and GM-CSF. An unidentified gliomareleased factor (?) stimulates toll-like receptor-2 (TLR2) in TAM and subsequently the p38-MAPK- and MYD88-pathway, then MT1-MMP is expressed and on the plasmamembrane of TAM. MT1-MMP on TAM proteolytically cleaves glioma-derived proMMP-2 (an inactive pro-enzyme), which is thereby converted into the active form (MMP2) that degrades the extracellular matrix (ECM) and promotes glioma invasion; matrix degradation can activate other TLRs in TAM and promote the accumulation of additional TAM.

Figure 3. Mechanisms by which glioma-associated myeloid cells promote tumour angiogenesis. TAM have increased activity of MMPs (like e.g. MMP9) that promotes the release of stem cell factor, which is a chemoattractive signal for bone marrow-derived 
endothelial progenitors; thereby TAM potentially participate in vasculogenesis (1). The chemokine CXCL12 induces the tropism of TAM to hypoxic areas that are not well vascularised or have aberrant vasculature (2), which may foster angiogenesis in these regions by the mechanisms describe in point-3. TAM activate ECM-modifying enzymes (MMPs) and release a variety of soluble factors (growth factors and cytokines) which have direct angiogenic effects (3). 
IFN-y

GM-CSF

IL-1 $\beta$

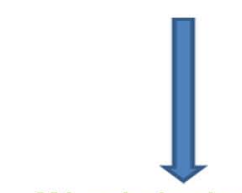

M1-polarized myeloid cell
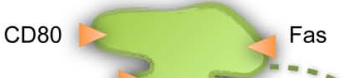

STAT-1
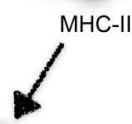

T cells adaptive anti-glioma response glioma cytotoxicity

ROS, NO

response
IL-4

IL-6

IL-10

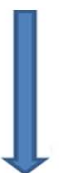

M2-polarized myeloid cell

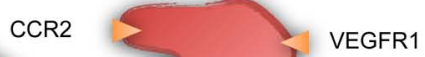

overlapping continuum

cytokines, chemokines

innate anti-glioma

glioma growth \& invasion 
recruitment of endothelial progenitors

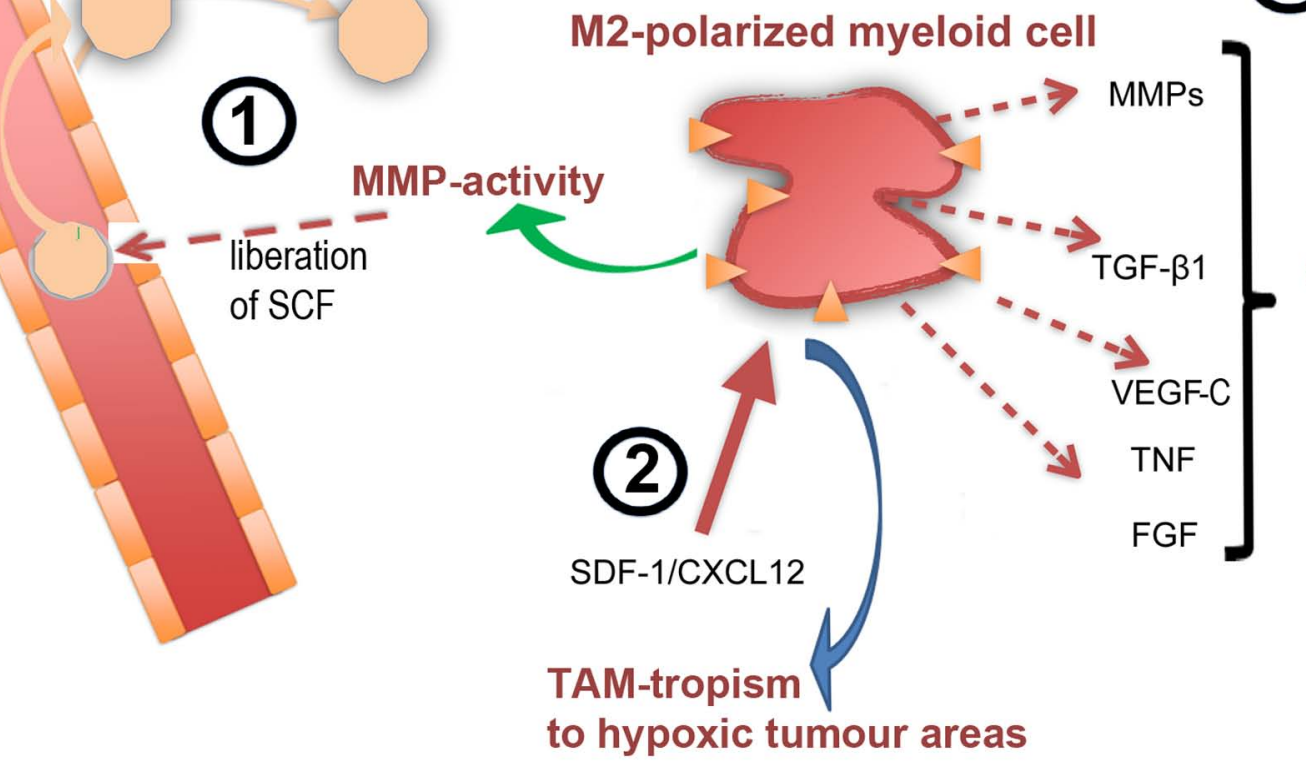

(3) $\varphi$

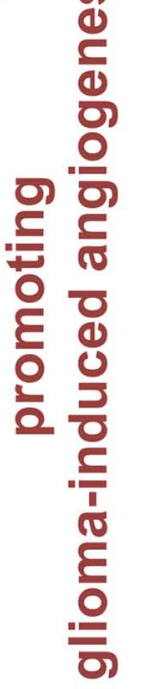

to hypoxic tumour areas 